of the close of the Conference itself. Copies of the Proceedings can be obtained, price 15s., if orders are received by the Low Temperature Conference Secretary, Clarendon Laboratory, Oxford, before the end of the year.

\section{Rhodes-Livingstone Museum}

A somewhat unusual museum report is that of the Rhodes-Livingstone Museum in Northern Rhodesia (Pp. 44. Livingstone: Rhodes-Livingstone Museum, 1951. 2s.). The period covered is 1934-51, and it includes an account not only of its first home in the old Magistrate's Court in Livingstone, but also its present position in the United Services Club building, to which it moved in 1937. Finally, new buildings were completed in November 1950 , mainly due to the generosity of local firms and private subscriptions. The aim in arranging the collections has been to create a friendly, pleasant atmosphere in which the visitor immediately feels at ease. Pale pastel shades predominate, and everything has been done to make a visit to the Museum a worthwhile adventure. The report also includes an excellent summary of the aims of museums in general and the policy of the Rhodes-Livingstone Museum in particular. This is a report of particular value to curators and all those who are interested in modern museum development.

\section{University of Birmingham}

Dr. O. E. Lowenstein, senior lecturer in zoology, University of Glasgow, has been appointed Mason professor of zoology in the University of Birmingham, in succession to Prof. P. B. Medawar. The following have been appointed lecturers in the University : Dr. H. R. Mulholland (mathematics); Dr. C. E. Harrold (botany); Dr. F. J. Wallace (mechanical engineering); and W. M. Crooks and D. C. Freshwater (chemical engineering). The following have been appointed research fellows in the University : Dr. J. M. Rushforth (mathematics); J. D. Lawson (geology); and Dr. A. R. Harding and T. Broom (metallurgy). The title of reader in thermodynamics has been conferred on Dr. F. K. Bannister, lecturer in the Department of Mechanical Engineering. Dr. R. T. W. Hall has resigned from his lectureship in chemical engineering on taking up an appointment with Esso Motor Spirit Co. at Fawley, Hants.

\section{The Night Sky in December}

Full moon occurs on Dec. 13d. 09h. 30m., U.T., and new moon on Dec. 28d. 11h. 43m. The following conjunctions with the moon take place : Dec. 7d. 10h., Jupiter $4^{\circ} \mathrm{S}$.; Dec. 22d. 23h., Saturn $6^{\circ} \mathrm{N}$.; Dec. 23d. 03h., Mars $6^{\circ}$ N. ; Dec. 25d. 14h., Venus $8^{\circ}$ N.; Dec. $27 \mathrm{~d}$. $06 \mathrm{~h}$., Mercury $8^{\circ} \mathrm{N}$. In addition to these conjunctions with the moon, Mars is in conjunction with Saturn on Dec. 19d. 13h., Mars being $0.7^{\circ} \mathrm{S}$. In the early part of the month Mercury sets about an hour after the sun and is in inferior conjunction with the sun on December 17, after which it becomes a morning star and at the end of the month rises nearly two hours before the sun. Venus, a morning star, rises at $3 \mathrm{~h} .20 \mathrm{~m} ., 3 \mathrm{~h} .55 \mathrm{~m}$. and $4 \mathrm{~h} .35 \mathrm{~m}$. on December 1,15 and 31 , respectively, stellar magnitude varying from -3.9 to -3.6 and the visible portion of the illuminated disk varying between 0.58 and 0.70 . Mars is a morning star, rising at $1 \mathrm{~h} .40 \mathrm{~m}$. on December 1 and at $23 \mathrm{~h}$. $50 \mathrm{~m}$. on December 31 ; in the early part of the month the planet is close to $\eta$ Virginis. Jupiter is visible up to about midnight, setting at $1 \mathrm{~h} .40 \mathrm{~m}$. and $23 \mathrm{~h} .50 \mathrm{~m}$. on December 1 and 31 , respectively. Saturn, a morning star, rises at $2 \mathrm{~h} .25 \mathrm{~m}$., $1 \mathrm{~h} .40 \mathrm{~m}$. and $0 \mathrm{~h} .40 \mathrm{~m}$. at the beginning, middle and end of the month, respectively, and in the last case is a little north-west of $\theta$ Virginis. Occultations of stars brighter than magnitude 6, observations being made at Greenwich, are as follows : Dec. 3d. 18h. 26.7m., 30 Cr.pr. $(D)$; Dec. 10d. 16h. $08.5 \mathrm{~m} ., \varepsilon$ Arie. $m$. $(D)$. $D$ refers to disappearance. The Geminid meteors are active during the first week of December. Winter solstice occurs on Dec. 22d. $16 \mathrm{~h}$.

\section{Announcements}

H.R.H. The DUke of Edinburgh will open the new laboratories at Stoke-on-Trent of the British Ceramic Research Association on December 12.

Prof. Albert Vandel, professor of zoology in the University of Toulouse, has been elected a correspondant for the Section of Anatomy and Zoology of the Paris Academy of Sciences in succession to Prof. Emile Guyénot, professor of zoology and comparative anatomy in the University of Geneva, who has been elected a non-resident member of the Academy.

THE degree of D.Se. in the University of London has been conferred on D. R. Bates (University College), Prof. C. H. Gray (King's College Hospital Medical School) and Miss Florence N. David (University College).

THE Centre National de Coordination des Études et Recherches sur la Nutrition et l'Alimentation is arranging a symposium on meat production, to be held in Paris during December 18-20, at which scientific research workers and technologists will present papers on different aspects of the subject, both from the point of view of the producer and from that of the consumer. Further information can be obtained from the Secrétariat, Centre National de Coordination des Etudes et Recherches sur la Nutrition et l'Alimentation, 71 Boulevard Péreire, Paris, 17e.

THE annual exhibition of the Television Society will be held during December 28-29 at Century House, Shaftesbury Avenue, London, W.C.2. The exhibition will be open as follows: December 28, 6-9.30 p.m., members and friends; December 29, 10.30 a.m.5.0 p.m., members. The public is admitted by invitation card. All exhibits are closely related to television engineering or production or to the production of television programmes. Tickets of admission may be obtained from Society or patron members, or from the Lecture Secretary at 10 Tantallon Road, Balham, London, S.W.12.

THE Institute of Rural Life at Home and Overseas is organizing a conference entitled "Rural Life at Home and Overseas", to be held at High Leigh, Hoddesdon, Herts, during January 1-4, $195 \varepsilon$, under the chairmanship of the Rev. Dr. W. E. Farndale, a former president of the Methodist Conference and moderator of the Free Church Federal Council. Three lectures will be delivered: "Progress in British Agriculture", by Prof. H. G. Sanders; "A Sudan Experiment in Education", by V. L. Griffiths; and "The Church in the Village", by the Rev. A. K. Mathews. The fee for the conference (inclusive of board) is $£ 3$. Registration forms and further information can be obtained from the secretary of the Institute at 84 Eccleston Square, London, S.W.1. 